\title{
PRINSIP DASAR OPERASIONAL PERBANKAN SYARIAH
}

\author{
Achmad Baraba *)
}

\section{Pendahuluan}

$\mathrm{P}$

erkembangan perbankan Islam merupakan fenomena yang menarik kalangan akademisi maupun praktisi dalam 20 tahun terakhir. Tak kurang IMF juga telah melakukan kajian-kajian atas praktek perbankan Islam sebagai alternatif sistem keuangan internasional yang memberikan peluang upaya penyempurnaan sistem keuangan internasional, dimana belakangan ini dirasakan banyak sekali mengalami goncangan dan ketidakstabilan yang menyebabkan krisis dan keterpurukan ekonomi akibat lebih dominannya sektor finansial di banding sektor riil dalam hubungan perekonomian dunia.

Beberapa kajian menunjukkan bahwa laju pertumbuhan perdagangan uang dan derivasinya tumbuh kurang lebih 800 kali lipat dibanding laju pertumbuhan sektor riil, dan semakin tidak terintegrasinya kegiatan sektor riil dengan sektor moneter sehingga timbul berbagai distorsi dalam mengakselerasi pembangunan ekonomi dunia karena pengaruh yang sangat kuat dari perilaku ekonomi yang spekulatif dan tidak berbasis pada kondisi riil potensi ekonomi yangada.

Tidak lama sebelum terjadinya krisis mata uang di Asia khususnya Asia Tenggara, kawasan ini masih dinilai sebagai kawasan yang mempunyai laju pertumbuhan ekonomi yang menakjubkan oleh sebagian besar pakar dan lembaga keuangan internasional. Namun sebenarnya telah ada pula yang mengingatkan bahwa pertumbuhan tersebut lebih bersifat semu seperti gelembung sabun atau bal on karenatidak mencerminkan fundamental ekonomi yang kuat, yang tidak lain adal ah kekuatan riil ekonomi dengan tingkat produktifitas yang tinggi dan efisiensi ekonomi yang optimal.

Meskipun tidak semua mengakui secara terus terang tetapi disadari sepenuhnya bahwa sistem ekonomi yang berbasis kapital is dan interest base serta menempatkan uang sebagai komoditi yang diperdagangkan bahkan secara besar-besaran, ternyata memberikan implikasi yang serius terhadap kerusakan hubungan ekonomi yang adil dan produktif.

Pidato PM Malaysia, DR. Mahathir, pada sidang IMF di Hongkong tentang hal-hal tersebut diatas dianggap sangat fenomenal dan menggugah kesadaran berbagai pihak untuk setidak-tidaknya tergerak mempelajari lebih jauh kebenaran argumentasi yang muncul

*) Achmad Baraba : Konsultan Bidang Perbankan, Prasetyo Utomo \& Arthur Andersen, Jakarta, email : abaraba@indosat.net.id 
tentang kerusakan sistem keuangan dunia, bahkan belakangan Soros pun sudah mulai mengkritik sistem kapitalisyang kel ewat bebas dalam pengaturan arus keuangan dunia.

Secara politis dan praktis upaya memperkenalkan sistem keuangan berdasarkan pandangan Islam tersebut masih harus melewati jalan panjang, tidak saja dari segi pemantapan fondasi teoritis dan praktis tetapi lebih dari itu diperlukan kekuatan untuk meyakinkan kelompok pelaku utama keuangan internasional dan negara maju bahwa sistem keuangan yang berbasis pada prinsip ekonomi Islam dapat menjamin terselenggaranya perekonomian dunia yang lebih adil dan membawa kesejahteraan umat manusia sesuai dengan konsep Islam "rahmatan lil alamin"

Kajian atas kekayaan prinsip ekonomi Islam serta praktek ekonomi yang berlaku pada masa Rasulullah khususnya pada periode Madinah telah lama dilakukan, sehingga pada masa sekarang telah tumbuh dan berkembang berbagai pusat kajian akademis tentang ekonomi Islam khususnya tentang lembaga keuangan Islam diberbagai negara bahkan dinegaranon muslimsekal ipun, seperti di Harvard University A merika, beberapa universitas di London, Australiadan tentu saja di negara-negara berpenduduk muslim termasuk Mal aysia dan Indonesia.

\section{Konsep Dasar Ekonomi Islam}

Islam sebagai agama merupakan konsep yang mengatur kehidupan manusia secara komprehensif dan universal baik dalam hubungan dengan Sang Pencipta (H abluminA Ilah) maupun dalam hubungan sesama manusia ( $\mathrm{H}$ ablumminannas). A da tiga pilar pokok dal am ajaran Islam yaitu :

$\sqrt{ }$ A qidah : komponen ajaran Islamyang mengatur tentang keyakinan atas keberadaan dan kekuasaan Allah, sehingga harus menjadi keimanan seorang muslim manakala melakukan berbagai aktivitas dimuka bumi semata-mata untuk mendapatkan keridlaan Allah dan sebagai khalifah yang mendapat amanah dari Allah.

$\sqrt{ }$ Syariah : komponen ajaran Islam yang mengatur tentang kehidupan seorang muslim baik dalam bidang ibadah (habluminAllah) maupun dalam bidang muamalah (hablumminannas) yang merupakan aktual isasi dari aqidah yang menjadi keyakinannya. Sedangkan muamalah sendiri meliputi berbagai bidang kehidupan, antara lain yang menyangkut ekonomi atau harta dan perniagaan disebut muamalah maliyah.

$\sqrt{ }$ A khlaq : landasan perilaku dan kepribadian yang akan mencirikan dirinya sebagai seorang muslim yang taat berdasarkan syariah dan aqidah yang menjadi pedoman 
hidupnya, sehingga disebut memiliki akhlaqul karimah sebagaimana hadis nabi yang menyatakan "Tidaklah sekiranya A ku diutus kecuali untuk menjadikan akhlaqul karimah"

Cukup banyak tuntunan Islam yang mengatur tentang kehidupan ekonomi umat, antara lain secara garis besar adalah sebagai berikut:

- Islam menempatkan fungsi uang semata-mata sebagai alat tukar dan bukan sebagai komoditi, sehingga tidak layak untuk diperdagangkan apalagi mengandung unsur ketidakpastian atau spekulasi (gharar) sehingga yang ada adalah bukan harga uang apalagi dikaitkan dengan berlalunya waktu tetapi nilai uang untuk menukar dengan barang.

- Riba dalam segala bentuknya dilarang bahkan dalam ayatAI-Qur'an tentang pelarangan riba yang terakhir yaitu surat AI Baqarah ayat 278-279 secara tegas dinyatakan sebagai berikut:

"H ai orang-orang yang beriman takutlah kepada A llah dan tinggal kanlah sisa-sisa riba itu jika kamu orang beriman. Kalau kamu tiada memperbuatnya ketahuilah ada peperangan dari A llah dan RasulN ya terhadapmu dan jika kamu bertobat maka untukmu pokok-pokok hartamu, kamu tidak menganiaya dan tidak pula teraniaya."

- Larangan riba juga terdapat dalam ajaran Kristen baik perjanjian Iama maupun perjanjian baru yang pada intinya menghendaki pemberian pinjaman pada orang lain tanpa meminta bunga sebagai imbalan.

- Meskipun masih ada sementara pendapat khususnya di Indonesia yang masih meragukan apakah bunga bank termasuk riba atau bukan, maka sesungguhnya telah menjadi kesepakatan ulama, ahli fikih dan Islamic banker yang menyatakan bahwa bunga bank adalah riba dan riba diharamkan.

- Tidak memperkenankan berbagai bentuk kegiatan yang mengandung unsur spekulasi dan perjudian, termasuk didalamnya aktivitas ekonomi yang diyakini akan mendatangkan kerugian bagi masyarakat.

- Harta harus berputar (diniagakan) sehingga tidak boleh hanya berpusat pada segelintir orang dan Allah sangat tidak menyukai orang yang menimbun harta sehingga tidak produktif, oleh karena itu bagi mereka yang mempunyai harta yang tidak produktif akan dikenakan zakat yang lebih besar dibanding jika diproduktifkan. Hal ini juga dilandasi ajaran yang menyatakan bahwa kedudukan manusia dibumi sebagai khalifah yang menerima amanah dari Allah sebagai pemilik mutlak segala yang terkandung didalam bumi dan tugas manusiauntuk menjadikan sebesar-besarnya bagi kemakmuran dan kesejahteraan manusia. 
- Bekerja dan atau mencari nafkah adalah ibadah dan wajib dilakukan, sehingga tidak seorangpun tanpa bekerja -- yang berarti siap menghadapi resiko -- dapat memperoleh keuntungan atau manfaat(bandingkan dengan perolehan bunga bank dari deposito yang bersifat tetap dan hampir tanpa resiko).

- Dalam berbagai bidang kehidupan termasuk dalam kegiatan ekonomi harus dilakukan secara transparan dan adil atas dasar suka sama suka tanpa paksaan dari pihak manapun.

- Adanya kewajiban untuk melakukan pencatatan atas setiap transaksi khususnya yang tidak bersifat tunai dan adanya saksi yang bisa dipercaya (simetri dengan profesi akuntansi dan notaris).

- Zakat sebagai instrumen untuk pemenuhan kewajiban penyisihan harta yang merupakan hak orang lain yang memenuhi syarat untuk menerima, demikian juga anjuran yang kuat untuk mengeluarkan infaq dan shodaqah sebagai manifestasi dari pentingnya pemerataan kekayaan dan memerangi kemiskinan.

Dari uraian ringkas diatas memberikan gambaran yang jelas tentang prinsip-prinsip dasar sistem ekonomi Islam dimana tidak hanya berhenti pada tataran konsep saja tetapi tersedia cukup banyak contoh-contoh kongkrit yang diajarkan oleh RasulAllah, yang untuk penyesuaiannya dengan kebutuhan saat sekarang cukup banyak ijtima' yang dilakukan oleh para ahli fikih disamping pengembangan praktek operasional oleh para ekonom dan praktisi lembaga keuangan Islam. Sesuai sifatnya yang universal maka tuntunan Islam tersebut diyakini akan selalu relevan dengan kebutuhan zaman, dalam hal ini sebagai contoh adalah pengembangan lembaga keuangan Islam seperti perbankan dan asuransi.

\section{Prinsip Dasar Operasional Bank Islam}

Sebagaimana diuraikan diatas prinsip-prinsip dasar sistem ekonomi Islam akan menjadi dasar beroperasinya bank Islamyaitu yang paling menonjol adalah tidak mengenal konsep bunga uang dan yang tidak kalah pentingnya adalah untuk tujuan komersial, Islam tidak mengenal peminjaman uang tetapi adalah kemitraan/ kerjasama (mudharabah dan musyarakah) dengan prinsip bagi hasil, sedang peminjaman uang hanya dimungkinkan untuk tujuan sosial tanpa adanya imbalan apapun.

Didalam menjalankan operasinya fungsi bank Islam akan terdiri dari :

* Sebagai penerima amanah untuk melakukan investasi atas dana-dana yang dipercayakan oleh pemegang rekening investasi / deposan atas dasar prinsip bagi hasil sesuai dengan kebijakan investasi bank. 
* Sebagai pengelola investasi atas dana yang dimiliki oleh pemilik dana / sahibul mal sesuai dengan arahan investasi yang dikehendaki oleh pemilik dana (dalam hal ini bank bertindak sebagai manajer investasi)

* Sebagai penyedia jasa Ialu lintas pembayaran dan jasa-jasa lainnya sepanjang tidak bertentangan dengan prinsip syariah

* Sebagai pengel ola fungsi sosial seperti pengelolaan dana zakat dan penerimaan serta penyaluran dana kebajikan ( fungsi optional )

Dari fungsi tersebut maka produk bank Islam akan terdiri dari :

\section{a. Prinsip mudharabah,}

yaitu perjanjian antara dua pihak dimana pihak pertama sebagai pemilik dana/ sahibul mal dan pihak kedua sebagai pengel ola dana/ mudharib untuk mengelola suatu kegiatan ekonomi dengan menyepakati nisbah bagi hasil atas keuntungan yang akan diperoleh, sedangkan kerugian yang timbul adalah resiko pemilik dana sepanjang tidak terdapat bukti bahwa mudharib melakukan kecurangan atau tindakan yang tidak amanah (misconduct).

Berdasarkan kewenangan yang diberikan kepada mudharib maka mudharabah dibedakan menjadi mudharabah mutlaqah dimana mudharib diberikan kewenangan sepenuhnya untuk menentukan pilihan investasi yang dikehendaki, sedangkan jenis yang lain adalah mudharabah muqayyaddah dimana arahan investasi ditentukan oleh pemilik dana sedangkan mudharib bertindak sebagai pelaksana/ pengelola.

\section{b. Prinsip M usyarakah,}

yaitu perjanjian antara pihak-pihak untuk menyertakan modal dalam suatu kegiatan ekonomi dengan pembagian keuntungan atau kerugian sesuai nisbah yang disepakati Musyarakah dapat bersifat tetap atau bersifat temporer dengan penurunan secara periodik atau sekaligus diakhir masa proyek.

\section{Prinsip Wadiah,}

adalah titipan dimana pihak pertama menitipkan dana atau benda kepada pihak kedua selaku penerima titipan dengan konsekuensi titipan tersebut sewaktu-waktu dapat diambil kembali, dimana penitip dapat dikenakan biaya penitipan.

Berdasarkan kewenangan yang diberikan maka wadiah dibedakan menjadi wadiah ya dhamanah yang berarti penerimatitipan berhak mempergunakan dana/ barang titipan untuk didayagunakan tanpa ada kewajiban penerima titipan untuk memberikan imbalan kepada penitip dengan tetap pada kesepakatan dapat diambil setiap saat 
diperlukan, sedang disisi lain w adiah amanah tidak memberikan kewenangan kepada penerima titipan untuk mendayagunakan barang/ dana yang dititipkan.

\section{d. Prinsip Jual Beli (AI Buyu'),}

- M urabahah yaitu akad jual beli antara dua belah pihak dimana pembeli dan penjual menyepakati harga jual yang terdiri dari harga beli ditambah ongkos pembelian dan keuntungan bagi penjual. Murabahah dapat dilakukan selain secaratunai bisa juga secara bayar tangguh atau bayar dengan angsuran.

- Salam yaitu pembelian barang dengan pembayaran dimuka dan barang diserahkan kemudian

- Ishtisna' yaitu pembelian barang melalui pesanan dan diperlukan proses untuk pembuatannya sesuai dengan pesanan pembeli dan pembayaran dilakukan dimuka sekal igus atau secara bertahap.

e Jasa-Jasa,

- Ijarah yaitu kegiatan penyewaan suatu barang dengan imbalan pendapatan sewa, bila terdapat kesepakatan pengalihan pemilikan pada akhir masa sewa disebut Ijarah mumtahiya bi tamlik(sama dengan operating lease)

- Wakalah yaitu pihak pertama memberikan kuasa kepada pihak kedua (sebagai wakil) untuk urusan tertentu dimana pihak kedua mendapat imbalan berupa fee atau komisi.

- Kafalah yaitu pihak pertama bersedia menjadi penanggung atas kegiatan yang dilakukan oleh pihak kedua sepanjang sesuai dengan yang diperjanjikan, dimana pihak pertama menerima imbalan berupa feeatau komisi (garansi).

- Sharf yaitu pertukaran / jual beli mata uang yang berbeda dengan penyerahan segera / spot berdasarkan kesepakatan harga sesuai dengan harga pasar pada saat pertukaran

\section{f. Prinsip Kebajikan,}

yaitu penerimaan dan penyal uran dana kebajikan dalam bentuk zakat infaq shodaqah dan lainnya serta penyaluran al-qardhul hassan yaitu penyaluran dan dalam bentuk pinjaman dengan tujuan untuk menolong golongan miskin dengan penggunaan produktif tanpa diminta imbalan kecuali pengembalian pokok hutang.

Dari uraian diatas maka produk perbankan Islam dalam prakteknya dapat diringkas sebagai berikut: 


\begin{tabular}{||l|l||}
\hline \multicolumn{1}{|c|}{ Produk /Jasa } & \multicolumn{1}{c|}{ Prinsip Syariah } \\
\hline \hline Giro & Wadiah yadhamanah \\
\hline Tabungan & Wadiah yadhamanah mudharabah \\
\hline Deposito / rekening investasi bebas & Mudharabah \\
\hline Rekening investasi tidak bebas penggunaan & Mudharabah muqayyadah \\
\hline Piutang Murabahah & Murabahah tidak tunai \\
\hline Investasi Mudharabah & Mudharabah \\
\hline Investasi Musyarakah & Musyarakah \\
\hline Investasi assets untuk disewakan & ljarah \\
\hline Pengadaan barang untuk dijual atau dipakai sendiri & Salam atau ishtisna' \\
\hline Bank garansi & Kafalah \\
\hline Transfer, inkaso, L/ C, dll. & Wakalah \\
\hline Safe deposit box & Wadiah amanah \\
\hline Surat berharga & Mudharabah \\
\hline Jual beli valas (non speculative motive) & Sharf \\
\hline
\end{tabular}

\section{Prinsip Dasar Akuntansi Bank Islam}

Dengan prinsip operasi yang berbeda dengan bank konvensional memberikan implikasi perbedaan pada prinsip akuntansi baik dari segi penyajian maupun pelaporannya. Laporan akuntansi bank Islam akan terdiri dari :

- Laporan posisi keuangan / neraca

- Laporan laba-rugi

- Laporan arus kas

- Laporan perubahan modal

- Laporan perubahan investasi tidak bebas / terbatas

- Catatan atas laporan keuangan

- Laporan sumber dan penggunaan zakat

- Laporan sumber dan penggunaan dana qard/ qardul hasan

Beberapa hal yang menonjol dalam akuntansi bank Islam adalah :

- Giro dan tabungan wadiah dicatat/ disajikan sebagai hutang dalam neraca.

- Rekening investasi mudharabah bebas / deposito dicatat/ disajikan sebagai rekening tersendiri antara hutang dan modal (bukan hutang).

- Rekening investasi tidak bebas dicatat terpisah sebagai off balance sheet account dalam bentuk laporan perubahan posisi investasi tidak bebas.

- Piutang murabahah dicatat sebesar sisa hargajual yang belum tertagih dikurangi dengan margin yang belum diterima

- Investasi mudharabah dan musyarakah disajikan sebesar sisa nilai modal yang disertakan atau diinvestasikan 
- Aset yang disewakan dicatat sebesar harga perolehan dikurangi dengan akumulasi penyusutan.

- Pendapatan pada umumnya diakui secara cash basis sedang beban tetap secara accrual basis.

- Bagi hasil antara mudharib dan sahibul mal dilakukan atas profit loss sharing atau revenue sharing, sedangkan pendapatan bank yang berasal dari investasi dana sendiri atau dari danayang bukan berasal dari rekening investasi sepenuhnya menjadi pendapatan bank, disamping itu pendapatan jasa bank sepenuhnya menjadi pendapatan bank yang tidak dibagi hasilkan.

Prinsip akuntansi bank Islam mengacu pada Accounting and Auditing Standard for Islamic Financial Institution yang diterbitkan oleh A ccounting and A uditing Organization for Islamic Financial Institution yang berpusat di Bahrain yang didirikan pada tahun 1991 atas prakarsa IDB dan beberapa lembaga keuangan Islam besar dan sekarang telah mempunyai anggota hampir seluruh lembaga keuangan Islam.

Bank Indonesia bersama IAI saat ini sedang dalam proses untuk mengadopsi standard tersebut menjadi standar akuntansi bank syariah di Indonesia yang diharapkan selesai tahun ini.

\section{Penutup}

Dengan semakin kokohnya landasan hukum bank syariah di Indonesia melalui penyempurnaan Undang-undang no 7 tahun 1992 tentang Perbankan dengan Undangundang no 10 tahun 1998 yang kemudian dilengkapi dengan kebijakan Bank Indonesia berupaSurat Keputusan Direksi Bank Indonesia, dan melihat potensi yang ada baik didalam negeri maupun diluar negeri maka diperkirakan prospek tumbuh dan berkembangnya bank syariah di Indonesia akan menunjukkan perkembangan yang menggembirakan, mengingat adanya peluang bank konvensional untuk membuka cabang atau mengkonversi cabangnya menjadi cabang syariah.

Sementara itu sampai saat ini jumlah lembaga keuangan Islam diseluruh dunia telah mendekati jumlah 200 buah tersebar baik dinegara berpenduduk muslim maupun dinegara barat seperti di Inggris, Swiss, Denmark, dan lain-lain, juga di Amerika dan Australia dalam bentuk koperasi-koperasi.

Diharapkan sistem perbankan Islam atau bahkan sistem ekonomi Islamakan menjadi alternatif sistem yang mampu mengatasi ketimpangan sistem keuangan internasional yang sedang terpuruk dewasa ini.

Wallahualam. 